\title{
Salmonella Enteritidis forms biofilm under low temperatures on different food industry surfaces
}

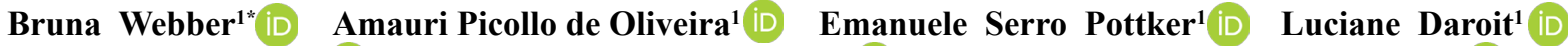 \\ Rafael Levandowski ${ }^{1}$ iD Luciana Ruschel dos Santos ${ }^{1}$ iD Vladimir Pinheiro do Nascimento ${ }^{2}$ iD \\ Laura Beatriz Rodrigues ${ }^{1}$ (iD)
}

\begin{abstract}
${ }^{1}$ Programa de Pós-Graduação em Bioexperimentação, Universidade de Passo Fundo (UPF), 99052-900, Passo Fundo, RS, Brasil. E-mail: brunahw@hotmail.com. "Corresponding author.

${ }^{2}$ Centro de Diagnóstico e Pesquisa em Patologia Aviária (CDPA), Faculdade de Veterinária, Universidade Federal do Rio Grande do Sul (UFRGS), Porto Alegre, RS, Brasil.

ABSTRACT: We evaluated the influence of temperature on the ability of Salmonella Enteritidis (SE) to form biofilms on stainless steel, polyethylene, and polyurethane surfaces under different hygiene procedures. These materials were placed on SE culture and incubated at $42 \pm 1{ }^{\circ} \mathrm{C}, 36 \pm 1{ }^{\circ} \mathrm{C}, 25 \pm 1{ }^{\circ} \mathrm{C}, 9 \pm 1{ }^{\circ} \mathrm{C}$, and $3 \pm 1{ }^{\circ} \mathrm{C}$ for $4,8,12$, and $24 \mathrm{~h}$. Hot water at $45^{\circ} \mathrm{C}$ and $85{ }^{\circ} \mathrm{C}$, $0.5 \%$ peracetic acid solution, and $1 \%$ quaternary ammonia were used for hygienization. Biofilm formation occurred at all temperatures evaluated, highlighting at $3{ }^{\circ} \mathrm{C}$ which has not been reported as an ideal temperature for the adhesion of SE to these materials. The SE adhered more often to polyethylene surfaces than to polyurethane and stainless steel surfaces $(P<0.05)$. Peracetic acid and water at $85{ }^{\circ} \mathrm{C}$ had similar hygienization efficiency $(P<0.05)$ followed by quaternary ammonia whereas water at $45{ }^{\circ} \mathrm{C}$ was not effective. SE adhered to these materials under low temperatures which to date have been deemed safe for food preservation.

Key words: Salmonella Enteritidis, biofilms, surfaces, hygiene procedures, food microbiology.
\end{abstract}

Salmonella Enteritidis forma biofilme sob baixas temperaturas em diferentes superfícies da indústria de alimentos

RESUMO: Avaliou-se o efeito da temperatura na capacidade de Salmonella Enteritidis (SE) formar biofilme em superficies de aço inoxidável, polietileno e poliuretano e diferentes processos de higienização. Corpos de prova destes materiais foram postos frente a culturas de SE e incubados a $42 \pm 1{ }^{\circ} \mathrm{C}, 36 \pm 1{ }^{\circ} \mathrm{C}, 25 \pm 1{ }^{\circ} \mathrm{C}, 9 \pm 1{ }^{\circ} \mathrm{C}$ e $3 \pm 1{ }^{\circ} \mathrm{C}$ por $4,8,12$ e 24 horas. Para a higienização foram testados água aquecida a $45^{\circ} \mathrm{C}$ e $85^{\circ} \mathrm{C}$ e soluções de ácido peracético $0,5 \%$ e amônia quaternária $1 \%$. Verificou-se a formação de biofilmes em todas as temperaturas avaliadas, ressaltando-se a $3{ }^{\circ} \mathrm{C}$, ainda não citada como propícia para adesão de SE. Houve maior adesão ao polietileno do que ao poliuretano $e$ ao aço inoxidável $(P<0.05)$. Para higienização, o ácido peracético e a água a $85{ }^{\circ} \mathrm{C}$ tiveram ação semelhante (P<0.05), seguidos por amônia quaternária, enquanto que a água a $45{ }^{\circ} \mathrm{C}$ não foi eficaz. Todos os materiais avaliados propiciaram a aderência de SE, mesmo sob temperaturas baixas, consideradas até então seguras para a conservação dos alimentos.

Palavras-chave: Salmonella Enteritidis, biofilmes, superficies, procedimentos de higienização, microbiologia de alimentos.

\section{INTRODUCTION}

Salmonella Enteritidis (SE) is the most common Salmonella serotype that affects humans. It is the main cause of outbreaks of foodborne illness, especially in Europe where it accounts for $85 \%$ of cases. According to data published by the EFSA (European Food Safety Authority), more than 100.000 cases of salmonellosis are reported in humans annually, generating more than 3 billion euros in expenses per year (MILJKOVIC-SELIMOVIC et al., 2010; EFSA, 2015; EFSA, 2017).
Based on data released by the World Health Organization (WHO), SE is one of the 15 serovars of Salmonella that most often occurs in humans, food, animals, environmental samples, and animal feed (WHO, 2016; WHO, 2017a).

It is considered one of the human enteropathogens most frequently associated with the alimentary tract of chickens, and originates from different poultry sources. Products such as eggs and meat are the most common source of pathogens that may cause infectious gastroenteritis in humans, and are responsible for up to $47 \%$ of all infections in people 
(CARDOSO et al., 2000; CDC, 2013). Therefore, the control of SE in poultry abattoirs is essential due to public health concerns (CDC, 2014a) and the economic impact of Salmonella to infections which cause losses to the domestic market and exports.

Another concern regarding the hygienicsanitary conditions in poultry abattoirs is biofilm formation. In this process, microorganisms attach to biotic and abiotic surfaces. These microorganisms manage to grow on these surfaces acting as sources of permanent contamination, releasing biofilms fragments formed by bacterial cells such as those from Salmonella spp., and may compromise microbiological quality and safety of food products (FUSTER-VALLS et al., 2008; FLEMMING et al., 2016).

Bacterial growth at refrigeration temperatures should be investigated since it is considered a critical point in food production and conservation (LIMA et al., 2004). Biofilm formation is influenced by a number of environmental parameters including temperature, $\mathrm{pH}$, osmolarity, and atmospheric pressure. This process increases as conditions become less favorable for the microorganism (RODE et al., 2007; REUTER et al., 2010; LIANOU \& KOUTSOUMANIS, 2012).

The SE is able to adhere and form biofilm on inert food processing surfaces such as stainless steel, polyethylene and polyurethane surfaces (MANIJEH et al., 2008) under different growth conditions and temperatures. It is reported that Salmonella does not grow below $5{ }^{\circ} \mathrm{C}$ (GAST, 2008; MOREY \& SINGH, 2012). TORTORA et al. (2012) showed that $5{ }^{\circ} \mathrm{C}$ is the minimum temperature, whereas $37^{\circ} \mathrm{C}$ is the optimal temperature for Salmonella grow.

Sessile bacteria are significantly more resistant to substances used in disinfection procedures (COSTERTON et al., 1995; STEENACKERS et al., 2012). Once the biofilm is formed, it acts as a physical barrier that prevents the action of sanitizing agents (COSTERTON et al., 1995; STEPANOVIC et al., 2004) which makes the elimination of pathogens in food processing facilities difficult. In this context, this study aimed to evaluate the influence of different temperatures and disinfection treatments in the biofilm formation by SE at different surfaces, simulating steps of industrial processing.

\section{MATERIALS AND METHODS}

Sources of SE

Two samples of Salmonella Enteritidis (SE) were evaluated. These bacterial specimens were cultured from samples of poultry cuts processed for consumers (SE 84) and from a drag swab used to sample a broiler premise (SE 106). Both were submitted to serology and confirmed by DNA microarray technique (Check and Trace, R-Biopharm AG, Darmstadt, Germany), which allows the simultaneous evaluation of the expression of thousands genes of a microorganism.

\section{Specimen preparation}

Polyurethane, polyethylene, and AISI 316 stainless steel coupons $1 \mathrm{~cm}^{2}$ in diameter and $0.1 \mathrm{~cm}$ thick were used. Coupons were manually cleaned with a sponge, water, and neutral liquid detergent, rinsed with distilled water, immersed in ethyl alcohol $70 \%(\mathrm{v} / \mathrm{v})$ for $1 \mathrm{~h}$ at room temperature, rinsed one more time, and sterilized in an autoclave at $121^{\circ} \mathrm{C}$ for 30 minutes.

\section{Biofilm formation tests}

For biofilm formation, coupons with bacteria were grown individually on sterile polystyrene 12-well cell culture plates $\left(\mathrm{Nest}^{\mathrm{B}} \mathrm{Biotech}\right.$ Co. Ltd, Rahway, NJ, USA) $2.75 \mathrm{~mL}$ of tryptic soy broth without glucose (TSB, Difco ${ }^{\circledR}$ Laboratories, Sparks, MD, USA) and $250 \mu \mathrm{L}$ of each SE culture with approximately $10^{3}$ UFC. $\mathrm{mL}^{-1}$ were inoculated in each well and verified by culture in Plate Count Agar (PCA, HiMedia ${ }^{\circledR}$ Laboratories, Mumbai, India).

Coupons were immersed in SE 104 and SE 86 cultures and incubated at $42 \pm 1{ }^{\circ} \mathrm{C}, 36 \pm 1$ ${ }^{\circ} \mathrm{C}, 25 \pm 1{ }^{\circ} \mathrm{C}, 9 \pm 1{ }^{\circ} \mathrm{C}$, and $3 \pm 1{ }^{\circ} \mathrm{C}$, reproducing the environmental temperatures for food processing which were optimal for thermo-tolerant microorganisms. These were evaluated at $0,4,8,12$, and $24 \mathrm{~h}$, simulating pre-operational and operational hygiene stages in poultry abattoirs (ROSSONI \& GAYLARDE, 2000; KUSUMANINGRUM et al., 2003) in triplicate.

At specific times, the coupons were removed from culture medium with sterile tweezers, immersed in $5 \mathrm{~mL}$ of Peptone Water $0.1 \%$ (AP, HiMedia ${ }^{\circledR}$ Laboratories. Mumbai, India) for 1 minute for removal of planktonic cells, placed in tubes with Peptone Water $0.1 \%$, and sonicated for 10 minutes on ultrasound $(40 \mathrm{kHz}$ and $81 \mathrm{~W})$ for the release of sessile cells (SCHERBA et al., 1991). Five $10 \mu \mathrm{L}$ drops of each dilution were inoculated in PCA agar by drop plate technique and incubated for $24 \mathrm{~h}$ at $37 \pm 1{ }^{\circ} \mathrm{C}$.

For calculation of results, the following formula was used: UFC.cm ${ }^{-2}=\left(\mathrm{V}_{\mathrm{D}} / \mathrm{V}_{\mathrm{A}}\right)$.Av.D/A in which $\mathrm{V}_{\mathrm{D}}$ was the diluent volume used in rinsing $(5 \mathrm{~mL}), \mathrm{V}_{\mathrm{A}}$ the aliquot volume used in plating $(0.05 \mathrm{~mL}$ or $0.1 \mathrm{~mL})$, $\mathrm{Av}$ the average count recovered from plates (UFC), D 
the dilution used in counting, and A the coupon area $\left(2 \mathrm{~cm}^{2}\right)$ expressed in $\log ^{10}$. UFC.cm² $($ GIBSON, 1999; ISO, 18593:2012).

\section{Biofilm removal tests}

After planktonic cells were removed, coupons were placed in $5 \mathrm{~mL}$ of sterile water and heated at $45^{\circ} \mathrm{C}$ or $85{ }^{\circ} \mathrm{C}$ for 3 minutes and in $0.5 \%$ peracetic acid solution $\left(\right.$ Kalykim $^{\circledR}$, Alvorada, RS, Brazil) or $1 \%$ quaternary ammonia $\left(\right.$ Kalykim $^{\circledR}$, Alvorada, RS, Brazil) for 5 minutes, and the control it was water at room temperature.

After that, coupons were immersed in 5 $\mathrm{mL}$ of peptone water $0.1 \%$ with universal neutralizer (composed by $0.2 \%$ soy lecithin, $2 \%$ tween, $0.25 \%$ sodium thiosulphate, $0.1 \%$ peptone water and $1 \mathrm{~L}$ distillated water) for 1 minute (JOSEPH et al., 2001; ISO, 18593:2012), were placed into tubes with $5 \mathrm{~mL}$ of peptone water $0.1 \%$, sonicated, and inoculated by drop plate as described for the biofilm formation in the previous section.

\section{Scanning electron microscopy}

Scanning electron microscopy (SEM) was used to study surface microtopography. The scanning electron microscopy studies were carried out at the Electron Microscopy Center (CME), UFRGS - Federal University of Rio Grande do Sul, Porto Alegre, RS,
Brazil (SOUZA, 1998). Coupons were immersed in 10 $\mathrm{mL}$ of PBS (KH2PO4, s0.31 M, pH 7.2) for 1 minute for the removal of planktonic cells, and were then fixed in glutaraldehyde $2.5 \%$.

After that they were rinsed with $0.2 \mathrm{M}$ phosphate buffer. Coupons were dehydrated with acetone at $30 \%, 50 \%, 70 \%, 90 \%$, and $100 \%$. After complete dehydration, samples were subjected to critical point drying with $\mathrm{CO}_{2}$ preserved the microorganisms present and then were placed on stubs for metallization.

\section{Statistical analysis}

The average comparison was carried out with the Tukey test at 5\% of probability, and results were analyzed by variance (ASSISTAT version 7.7 beta, SILVA, 2016).

\section{RESULTS AND DISCUSSION}

Biofilm formation at different temperatures and surfaces Salmonella Enteritidis samples from poultry origin formed biofilm on stainless steel, polyethylene, and polyurethane surfaces. There was significant adhesion compared other materials $(\mathrm{P}<0.05)$ of both $\mathrm{SE}$ to the polyethylene surface (Figure 1, 2 and 3, Table 1). There was no significant difference in adhesion when SE 84 strain was

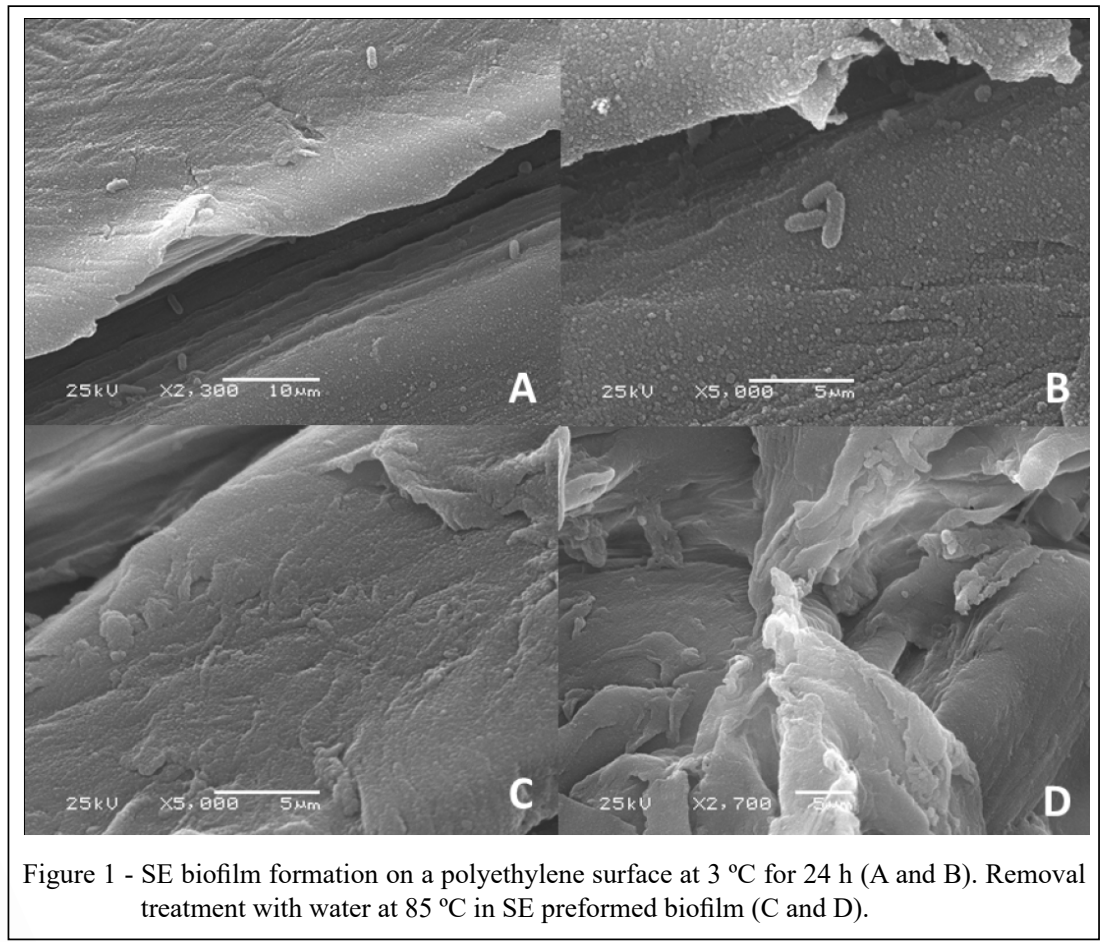

Ciência Rural, v.49, n.7, 2019. 


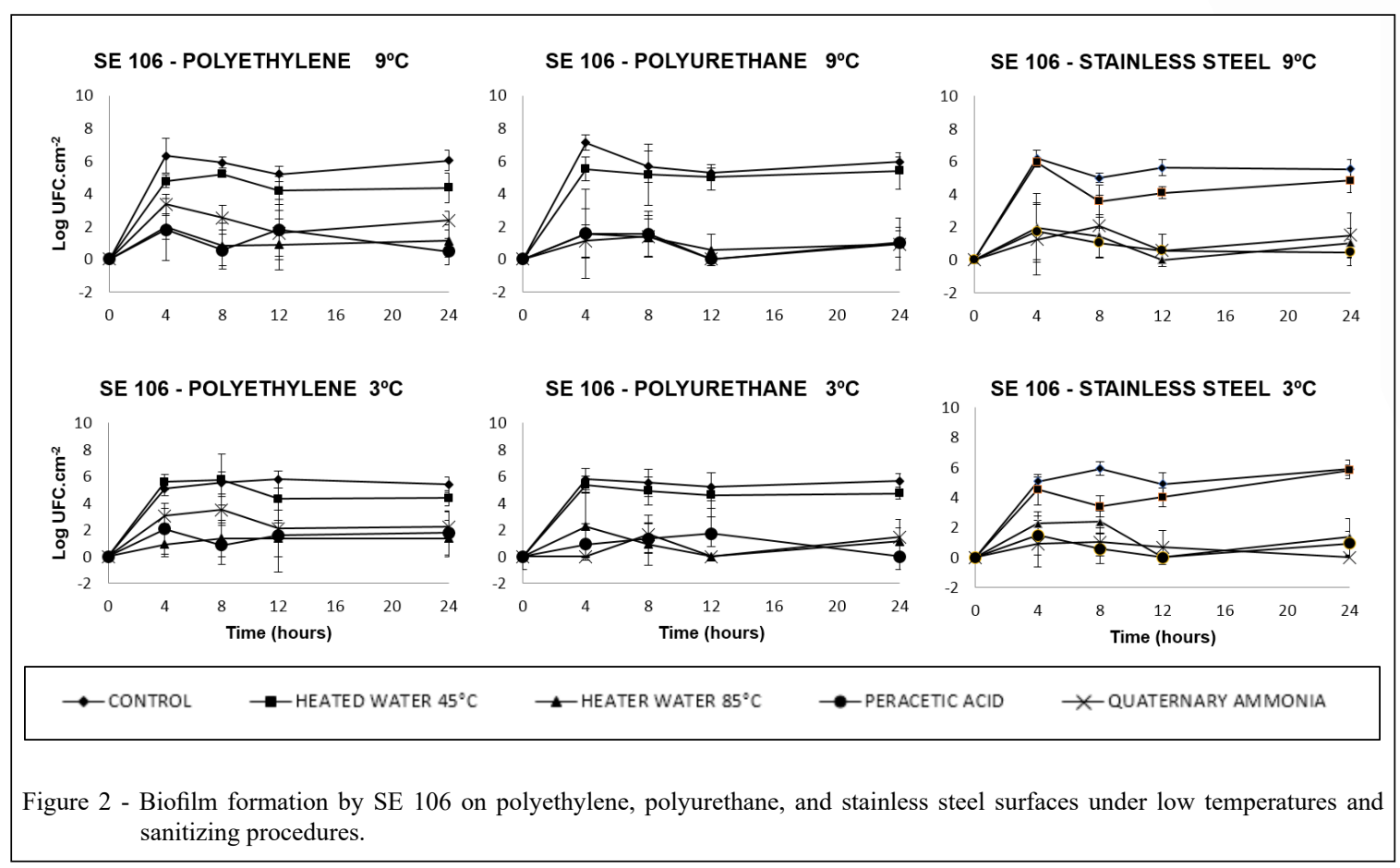

incubated at $3{ }^{\circ} \mathrm{C}$ or $9{ }^{\circ} \mathrm{C}$ (both of which are refrigeration temperatures) (Figure 2 and 3). Higher adhesion $(\mathrm{P}<0.05)$ was observed at $25^{\circ} \mathrm{C}, 36^{\circ} \mathrm{C}$, and $42{ }^{\circ} \mathrm{C}$. SE 106 showed biofilm formation at $3{ }^{\circ} \mathrm{C}, 9^{\circ} \mathrm{C}$, $25{ }^{\circ} \mathrm{C}$, and $36{ }^{\circ} \mathrm{C}$. There was a higher rate $(\mathrm{P}<0.05)$ of biofilm formation at $42{ }^{\circ} \mathrm{C}$, which is the selective enrichment temperature for Salmonella.

According to RONNER \& WONG (1993), at least $10^{3}$ UFC $\left(3 \log ^{10}\right.$. UFC. $\left.\mathrm{cm}^{-2}\right)$ and $10^{5}$ UFC (5 $\log ^{10}$.UFC. $\mathrm{cm}^{-2}$ ) adhered by $\mathrm{cm}^{2}$ are required for characterization of biofilm formation. Thus, it characterized our findings of SE 84 and SE 106 as biofilm formers, according data presented in table 1 and figure 4.

Virulence genes (hilA, avrA, invA, $s i v \mathrm{H}, s o p \mathrm{E}, s p i \mathrm{~A}, a g f \mathrm{~A}, l p f \mathrm{~A}, s e f \mathrm{~A}, s p v \mathrm{C})$ from the bacterial strains used in this study were previously investigated (SILVA et al., 2014). Only SE 84 strain had spiA gene, which is involved in both biofilm formation and virulence. It is important to note that the fimbrial agfA gene was not detected, whose main function is to promote the initial interaction of the bacterium with the host intestine, which is also related to biofilm formation (DONG et al., 2011). This finding showed that there are significant differences between Salmonella spp. serovars on their ability to form biofilms (VESTBY et al., 2009; WANG et al., 2013) as well as the influence of environmental parameters in SE biofilm formation. Biofilm formation tends to increase when conditions for the microorganism are unfavorable (LIANOU \& KOUTSOUMANIS, 2012).

Personnel working at these facilities in Brazil should make sure that temperatures above 10 ${ }^{\circ} \mathrm{C}$ are not used in the cutting room and that cooling temperatures of products do not exceed $4{ }^{\circ} \mathrm{C}$, to ensure the quality of products sold in Brazil and foreign markets (BRAZIL, 1998).

Based on this assumption, in the present study, recommended temperatures were simulated (reproduced in the laboratory) which are $3 \pm 1{ }^{\circ} \mathrm{C}$ (cooling temperature), $9 \pm 1{ }^{\circ} \mathrm{C}$ (room temperature according to the EU), $25 \pm 1{ }^{\circ} \mathrm{C}$ (room temperature), $36 \pm 1{ }^{\circ} \mathrm{C}$ (optimal growth temperature for mesophiles) and $42 \pm 1{ }^{\circ} \mathrm{C}$ (selective enrichment temperature for Salmonella). To the authors' knowledge, this is the first publication on SE biofilm formation at $3{ }^{\circ} \mathrm{C}$ on the surfaces evaluated. Our findings emphasized the fact that this specific temperature has not been described in the literature as ideal for the growth of Salmonella spp.

REUTER et al. (2010) and RODE et al. (2007) cite that sessile microorganisms are better adapted to the environment. Such ability enables them to survive and multiply under harmful, unfavorable and stressful conditions, which would explain SE 


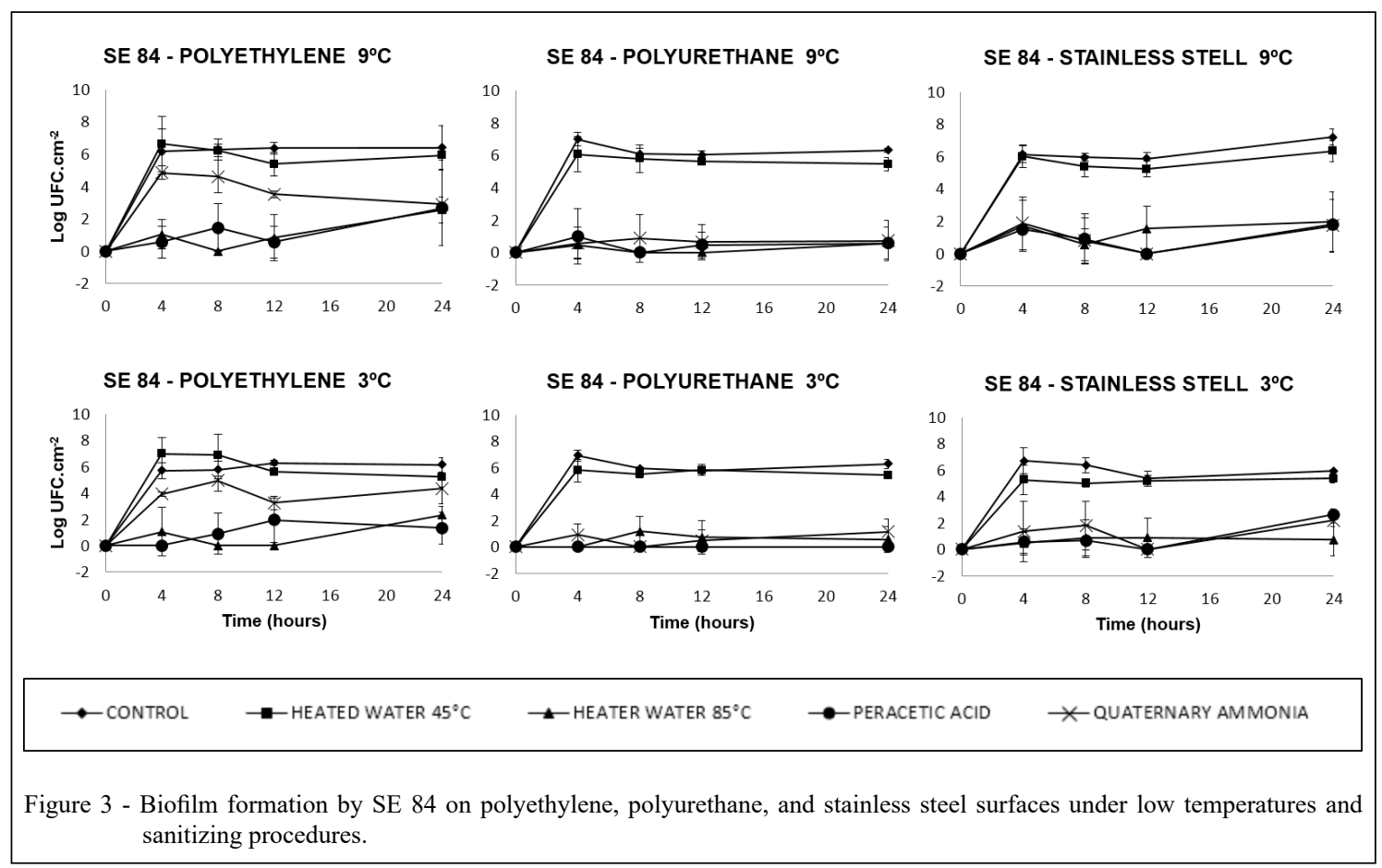

biofilm formation in our study. YANG et al. (2016) also related Salmonella Enteritidis as biofilm former at $4{ }^{\circ} \mathrm{C}$ under environmental food-related stress conditions and its resistance to chlorine treatment suggesting that stress conditions encountered in food processing may alter the resistance of $S$. Enteritidis biofilm in the disinfection treatment.

TORTORA et al. (2012) suggested that the minimum temperature for Salmonella growth is $5{ }^{\circ} \mathrm{C}$ whereas MOREY \& SINGH (2012) mentioned that this bacterium does not grow between $4{ }^{\circ} \mathrm{C}$ and $8{ }^{\circ} \mathrm{C}$. In addition, the pathogen modeling program version 8.0 used by the United States Department of Agriculture (USDA, 2017) established that $5{ }^{\circ} \mathrm{C}$ is the lowest temperature possible for the growth of Salmonella spp.

\section{Biofilm removal}

We noticed that peracetic acid $(0.5 \%)$ and water heated to $85{ }^{\circ} \mathrm{C}$ removed biofilms formed by $\mathrm{SE}$ at all temperatures and times with similar efficacy $(\mathrm{P}>0.05)$ followed by quaternary ammonia (1\%) (Figure 4 and Table 1). Water at $45^{\circ} \mathrm{C}$ had no effect on biofilm removal compared to the control.

According to the studies published by VIALTA et al. (2002), sanitation operation efficiency of an equipment or surface is measured by the number of viable microorganisms adhered to it after this operation. In general, equipment should not contain more than 100 UFC. $\mathrm{cm}^{-2}$. In UE Directive 471/2001, the maximum level accepted for surface testing is 10 UFC. $\mathrm{cm}^{-2}$ of mesophilic microorganisms and 1 UFC. $\mathrm{cm}^{-2}$ of enterobacteria. Establishments authorized to export avian products to members of the European Union must comply with this directive (EUROPEAN UNION, 2001a).

According to the American Public Health Association (APHA, 2014), physical or chemical sanitizers should reduce the number of microorganisms by up to $2 \mathrm{UFC} . \mathrm{cm}^{-2}$ on surfaces so that they can be considered hygienic. According to the European Standard EN 13697:2001 for surface testing in the European Union, there should have a reduction of at least 4 log in adhered surfaces (EUROPEAN UNION, 2001b; MORETRO et al., 2009).

In our study, there was a reduction of $4.23 \log _{10}$ UFC.mL $L^{-1}$ after 5 minutes of contact with peracetic acid $(0.5 \%), 3.562 \log _{10}$ UFC.mL $\mathrm{m}^{-1}$ with quaternary ammonia $(1 \%)$, and $4.26 \log _{10} \mathrm{UFC} \cdot \mathrm{mL}^{-1}$ with water heated at $85^{\circ} \mathrm{C}$ after 3 minutes of contact. Water heated at $45^{\circ} \mathrm{C}$ did not meet the surface hygiene recommendations, reducing only 0.511 $\log _{10}$ UFC. $\mathrm{mL}^{-1}$ (Table 1). This result highlighted the non-use of water pressure in our study, which is recommended by CONTRERAS et al. (2003) in the rinsing step of surfaces, highlighting its importance. 


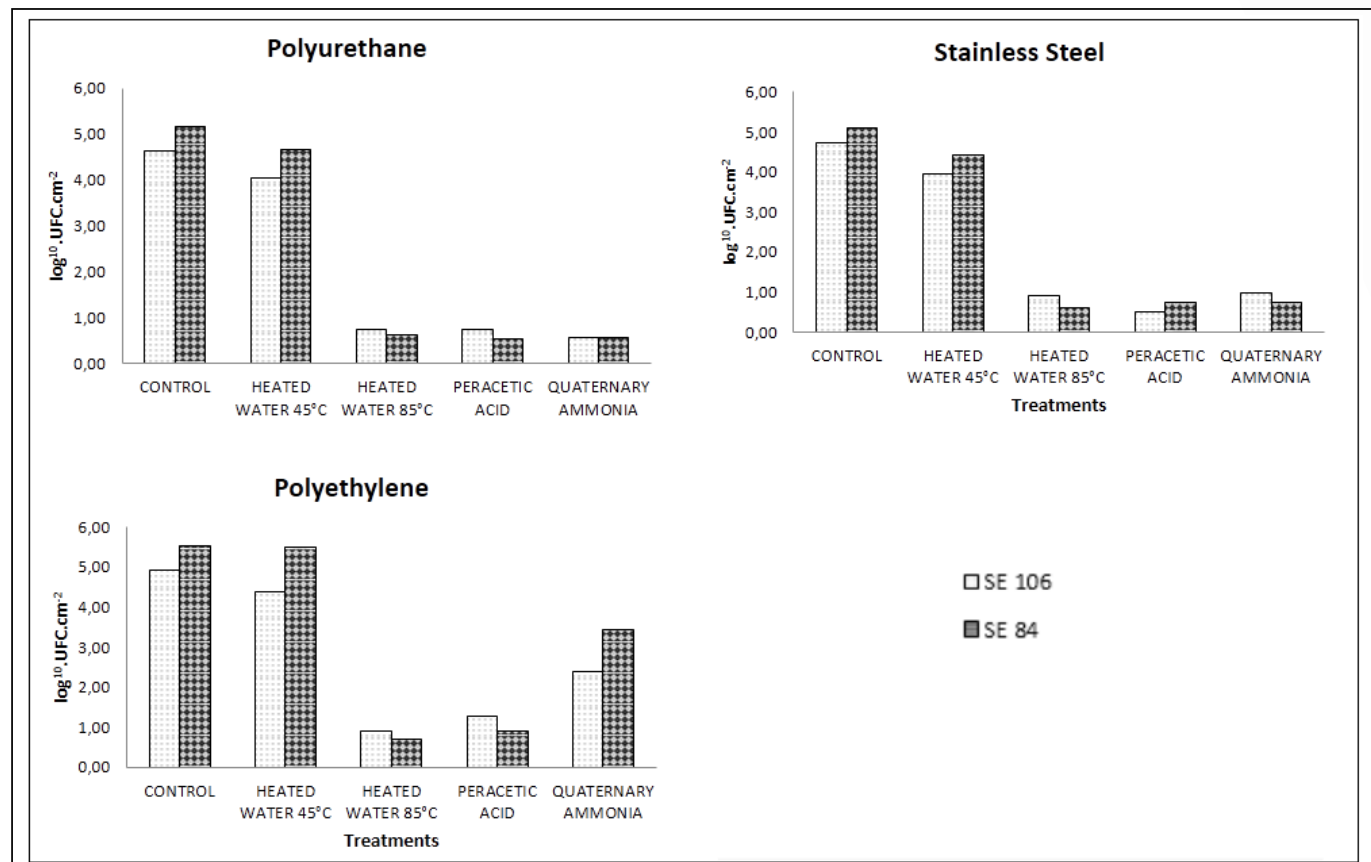

Figure 4 - Removal of biofilm formed by SE of poultry origin on stainless steel, polyethylene and polyurethane surfaces by different hygiene procedures.

Abbreviations: Heat water $45^{\circ} \mathrm{C}$ : sterile water heated at $45^{\circ} \mathrm{C}$; Heat water $85^{\circ} \mathrm{C}$ : sterile water heated at $85^{\circ} \mathrm{C}$; Peracetic acid $(0.5 \%)$; Quaternary ammonia $(1 \%)$.

Considering the existence of several hygienization agents such as chlorine solution, iodine solution and biguanide, we emphasized the use of peracetic acid and quarternary ammonia at these concentrations and times, because were used due to manufacturer's indication and preliminary tests conducted by our research group. In a study performed by Silva et al. (2014) all concentrations of quaternary ammonia $(0.3 \%, 1.0 \%$ and $2.0 \%)$ and peracetic acid $(0.1 \%, 0.5 \%$ and $1.0 \%)$ at all times tested (1, 5, 10 and $15 \mathrm{~min})$ were efficient in biofilm removal of $S$. Enteritidis.

According to the results of the present study, the most effective choice for SE biofilm removal on the evaluated surfaces normally used in abattoirs would be the application of peracetic acid as a sanitizing agent and water at $85^{\circ} \mathrm{C}$ for the utensils.

On the surfaces assessed, higher biofilm formation was observed in polyethylene coupons $\left(4.917 \log ^{10}\right.$.UFC. $\left.\mathrm{cm}^{-2}\right)$. This is probably due to the

Table 1 - Removal quantification of biofilm formed by SE (Salmonella Enteritidis) strains of poultry origin before disinfection procedures. Repetitions average.

\begin{tabular}{|c|c|c|c|c|c|}
\hline \multirow[t]{2}{*}{ Strain } & \multicolumn{5}{|c|}{ 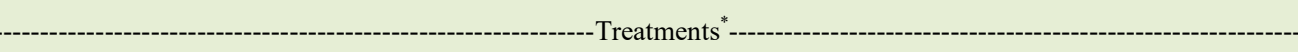 } \\
\hline & Control & Water at $45^{\circ} \mathrm{C}$ & Water at $85^{\circ} \mathrm{C}$ & Peracetic acid $(0.5 \%)$ & Quaternary ammonia (1\%) \\
\hline SE 84 & $5.258^{\mathrm{Aa}}$ & $4.875^{\mathrm{Ba}}$ & $0.649^{\mathrm{Ca}}$ & $0.725^{\mathrm{Ca}}$ & $1.580^{\mathrm{Da}}$ \\
\hline SE 106 & $4.765^{\mathrm{Aa}}$ & $4.126^{\mathrm{Ba}}$ & $0.854^{\mathrm{Ca}}$ & $0.836^{\mathrm{Ca}}$ & $1.317^{\mathrm{Da}}$ \\
\hline
\end{tabular}

Means followed by the same letters, uppercase in rows and lowercase in columns do not differ amongst themselves ( $\mathrm{P} \leq 0.05)$ by Tukey's test $(\mathrm{P}<0.05)$.

${ }^{*}$ Results expressed in $\log ^{10}$.UFC. $\mathrm{cm}^{-2}$. 
irregularities that are present on its surface which facilitates deposition of organic materials and also hinders the action of disinfectants (SINDE \& CARBALLO, 2000). There is lower biofilm formation on stainless steel coupons $\left(4.745 \log ^{10}\right.$. UFC. $\mathrm{cm}^{-2}$ ) and polyurethane coupons (4.633 $\log ^{10}$. UFC. $\mathrm{cm}^{-2}$ ) possibly because these two types of surfaces are less irregular than those of polyethylene coupons. However, OLIVEIRA et al. (2006) suggested that the depth of the surface imperfections may result in higher microbial adhesion than surface roughness distance.

\section{CONCLUSION}

Our results showed that Salmonella Enteritidis formed biofilm at low temperatures and short contact times, which difficult to disinfect food industry surfaces and the possibility of crosscontamination during food processing.

\section{ACKNOWLEDGEMENTS}

The authors would like to thank FAPERGS (001/2013 GR, Project: 1997-2551/13), RS - Brazil, for the financial support to conduct this study, and CAPES/FAPERGS/ UPF, Brazil, for the scholarship awarded.

\section{DECLARATION OF CONFLICT OF} INTERESTS

The authors declare no conflict of interest. The founding sponsors had no role in the design of the study; in the collection, analyses, or interpretation of data; in the writing of the manuscript, and in the decision to publish the results.

\section{REFERENCES}

APHA, American Public Health Association. 2014. Available from: <http://www.apha.org/>. Accessed: May, 14, 2018.

BRAZIL, Ministry of Agriculture and Supply. Normative Instruction $n^{\circ} 210,10$ November 1998. Technical regulation of technological and hygienic-sanitary inspection of poultry meat. Official Diary of the Union of March, $5^{\text {th }}$. 1999, section 1, p.17. 1998. Available from: <https://www.agencia.cnptia.embrapa.br/ Repositorio/Portaria-210_000h19kjcan02wx7ha0e2uuw60rmjy11. pdf $>$. Accessed: Jun. 5, 2018.

CARDOSO, A.L.S.P. et al. Research of Salmonella sp., fecal coliforms, total coliforms and mesofilos in carcass of broiler and derived products. Archives of Biological Institute, v.67, p.1, 2000. Available from: <https://www.cabdirect.org/ cabdirect/abstract/20023110100>. Accessed: May, 20, 2018. doi: 20023110100

CDC, Center for Disease Control. CDC and Food Safety, 2014a. Available from: <http://www.cdc.gov/foodsafety/cdcand-food-safety.html>. Accessed: Jun. 3, 2018
CDC, Center for Disease Control. Making Food Safer to Eat: Reducing contamination from the farm to the table. 2013. Available from: <http://www.cdc.gov/vitalsigns/foodsafety/>. Accessed: Jun. 3, 2015.

CONTRERAS, C.J. et al. Hygiene and Sanitation in the meat industry. São Paulo: Varela, p.180. 2003.

COSTERTOn, J.W. et al. Microbial biofilmes. Annual Review of Microbiology, v.49, p.711-745, 1995. Available from: <https:// www.annualreviews.org/doi/abs/10.1146/annurev.mi.49.10019 5.003431 ?journalCode=micro $>$. Accessed: May, 25, 2018. doi: 10.1146.49.100195.003431.

DONG, H. et al. Roles of the spiA gene from Salmonella Enteritidis in biofilm formation and virulence. Microbiology, v.157, p.1798 1805, 2011. Available from: $<$ https://www.ncbi.nlm.nih.gov/pmc/ articles/PMC3167914/>. Accessed: May, 21, 2018. doi: 10.1099/ mic.0.046185-0.

EFSA, European Food Safety Authority. Salmonella. 2017. Available from: <https://www.efsa.europa.eu/en/topics/topic/ salmonella>. Accessed: Nov. 2, 2017.

EFSA, European Food Safety Authority. The European Union summary report on trends and sources of zoonoses, zoonotic agents and food-borne outbreaks in 2013. EFSA Journal. v.13, n.12, p.4329, 2015. Available from: <https://efsa.onlinelibrary.wiley. com/doi/epdf/10.2903/j.efsa.2015.3991>. Accessed: Nov. 5, 2018. doi: $10.2903 /$ j.efsa.2015.4329.

FLEMMING, et al. Biofilms: an emergent form of bacterial life. Nat Rev Microbiol, v.14, p.563-575, 2016. Available from: $<$ https://www.nature.com/articles/nrmicro.2016.94>. Accessed: Feb. 4, 2018. doi: 10.1038/nrmicro.2016.94.

FUSTER-VALLS, N. Effect of different environmental conditions on the bacteria survival on stainless steel surfaces. Food Control, v.19, p.308-314, 2008. Available from: <https://www.sciencedirect. com/science/article/pii/S0956713507000795>. Accessed: Nov. 5, 2018. doi: 10.1016/j.foodcont.2007.04.013.

GAST, R.K. Salmonella infections - Paratyphoid Infections. In: Saif, Y.M., et al. (eds.). Diseases of Poultry, Blackwell Publishing Professional, Ames, IA. p.636-665, 2008.

GIBSON, H. Effectiveness of cleaning techniques used in the food industry in terms of the removal of bacterial biofilms. Journal of Applied Microbiology, v.87, p.41-48, 1999. Available from: $<$ https://onlinelibrary.wiley.com/doi/abs/10.1 046/j.1365-2672.1999.00790.x>. Accessed: Nov. 5, 2018. doi: 10.1046/j.1365-2672.1999.00790.x.

ISO, 2012. 18593. Microbiology of food and animal feeding stuffs - Horizontal methods for sampling techniques from surfaces using contact plates and swabs. ABNT - Brazilian Association of Technical Standards. p.8. Available from: $<$ https:// doi.org/10.3403/03061822>. Accessed: Nov. 6, 2018. doi: $10.3403 / 03061822$.

JOSEPH, B. et al. Biofilm formation by Salmonella spp. on food contact surfaces and their sensitivity to sanitizers. International Journal of Food Microbiology, v.64, p.367372, 2001. Available from: <https://www.sciencedirect.com/ science/article/pii/S0168160500004669>. Accessed: Nov. 10, 2018. doi: 10.1016/s0168-1605(00)00466-9.

Ciência Rural, v.49, n.7, 2019. 
KUSUMANINGRUM, H.D. et al. Survival of foodborne pathogens on stainless steel surfaces and cross-contamination to foods. International Journal of Food Microbiology, v.83, p.227-236, 2003. Available from: <https://www.ncbi.nlm.nih.gov/ pubmed/12878381>. Accessed: Jun. 2, 2018. doi: 10.1016/s01681605(02)00540-8.

LIANOU, A.; KOUTSOUMANIS, K.P. Strain variability of the biofilm-forming ability of Salmonella enterica under various environmental conditions. International Journal of Food Microbiology, v.160, p.171-178, 2012. Available from: <https:/ www.sciencedirect.com/science/article/pii/S0168160512005193>. Accessed: Jun. 5, 2018. doi: 10.1016/j.ijfoodmicro.2012.10.002.

LIMA, E.S.C. et al. Isolation of Salmonella and Staphylococcus aureus at swine slaughtering as subsidy for HACCP, the Hazard analisys and critical control point system. Pesquisa Veterinária Brasileira, v.24, p.185-190, 2004. Available from: <http://www. scielo.br/pdf/pvb/v24n4/a03v24n4.pdf>. Accessed: Jun. 10, 2018. doi: 10.1590/S0100-736X2004000400003.

MANIJEH, M.; et al. Biofilm formation by Salmonella Enteritidis on food contact surfaces. Journal of Biological Science, v.8, p.502-505, 2008. Available from: <https://scialert.net/fulltext/? doi=jbs.2008.502.505>. Accessed: Jul. 12, 2018. doi: 10.3923/ jbs.2008.502.505.

MILJKOVIC-SELIMOVIC, B.; et al. Salmonella enterica subspecies enterica serovar Enteritidis - actualities and importance. Acta Medica Medianae, v.49, p.3, 2010. Available from: $<$ https:// www.researchgate.net/publication/47530850 SALMONELLA ENTERICA_SUBSPECIES_ENTERIC CA_SEROVAR_ ENTERITIDIS ACTUALITIES AND IMPORTANCE $>$. Accessed: Jul. 6, 2018. doi: 579.842:-̄616.981.49.

MORETRO, T. et al. Evaluation of efficacy of disinfectants against Salmonella from the feed industry. Journal of Applied Microbiology, v.106, p.1005-1012, 2009. Available from: <https:// onlinelibrary.wiley.com/doi/full/10.1111/j.1365-2672.2008.04067. x>. Accessed: Jul. 14, 2018. doi: 10.1111/j.1365-2672.2008.04067.x.

MOREY, A.; SINGH, S. Low-Temperature Survival of Salmonella spp. in a Model Food System with Natural Microflora. Foodborne Pathogens and Disease, v.9, p.218-223, 2012. Available from: $<$ https://www.ncbi.nlm.nih.gov/pubmed/22217013>. Accessed: Sep. 4, 2018. doi: 10.1089/fpd.2011.1016.

OLIVEIRA, F.A.; et al. Antimicrobial resistance in Salmonella Enteritidis from foods involved in human salmonellosis outbreaks in southern Brazil. The New Microbiologica, v.29, p.49-54, 2006. Available from: <https://www.ncbi.nlm. nih.gov/pubmed/16608125>. Accessed: Sep. 10, 2018. doi: 16608125

REUTER, M. et al. Biofilm formation by Campylobacter jejuni is increased under aerobic conditions. Applied and Environmental Microbiology, v.76, p.2122-2128, 2010. Available from: <https:// aem.asm.org/content/76/7/2122>. Accessed: Sep. 16, 2018. doi: 10.1128/AEM.01878-09.

RODE, T.M. et al. Different patterns of biofilm formation in Staphylococcus aureus under food-related stress conditions. International Journal of Food Microbiology, v.116, p.372-383, 2007. Available from: <https:/www.sciencedirect.com/science/ article/pii/S0168160507001626?via\%3Dihub>. Accessed: Sep. 18, 2018. doi: 10.1016/j.ijfoodmicro.2007.02.017.
RONNER, A.B.; WONG, A.C.L. Biofilm development and sanitizer inactivation of Listeria monocytogenes and Salmonella Typhimurium on stainless steel and buna-n rubber. Journal of Food Protection, v.56, p.750-758, 1993. Available from: $<$ https:// jfoodprotection.org/doi/pdf/10.4315/0362-028X-56.9.750>. Accessed: Sep. 19, 2018. doi: 10.4315/0362-028x-56.9.750.

ROSSONI, E.M.M.; GAYLARDE, C.C. Comparison of sodium hypoclorite and peracetic acid as sanitizing agents for stainless steel food processing surfaces using epifluorescence microscopy. International Journal of Food Microbiology, v.61, p.81-85, 2000. Available from: <https://www.sciencedirect.com/science/ article/pii/S016816050000369X?via\%3Dihub>. Accessed: Sep. 20, 2018. doi: 10.1016/s0168-1605(00)00369-x.

SCHERBA, G.; et al. Quantitative assessment of the germicidal efficacy of ultrasonic energy. Applied and Enviromental Microbiology, v.57, p.2079-2084, 1991. Available from: <https:// www.ncbi.nlm.nih.gov/pmc/articles/PMC183525/>. Accessed: Sep. 21, 2018. doi: 0099-2240/91/072079-06\$02.00/0.

SILVA, C. F. et al. Biofilm Former Salmonella Enteritidis are Multiresistant to Antibiotics. Acta Scientiae Veterinariae, v.42, p.1229, 2014. Available from: <https://www.researchgate.net/ publication/269335710_Biofilm_Former_Salmonella_Enteritidis are Multiresistant to Antibiotics $>$. Accessed: Sep. $1 \overline{5}, 2018$. doi: $10 . \overline{13} 140 / 2.1 .1850 .5288$.

SILVA, F.A.S. ASSISTAT: Versão 7.7 beta-2016. DEAG-CTRNUFCG - Updated April 1, Available from: <www.assistat.com>. Accessed: Feb. 16, 2018.

SINDE, E.; CARBALlO, J. Attachment of Salmonella sp. and Listeria monocytogenes to stainless steel, rubber and polytetrafluorethylene: the influence of free energy and the effect of commercial sanitizers. Food Microbiology, v.17, p.439-447, 2000. Available from: <https://www.sciencedirect.com/science/ article/pii/S0740002000903393>. Accessed: Oct. 20, 2018. doi: $10.1006 /$ fmic. 2000.0339 .

SOUZA, W. Basic techniques of electron microscopy applied to biological sciences. Rio de Janeiro: Society of Electronic Microscopy, 80p. 1998.

STEENACKERS, H. et al. Salmonella biofilms: An overview on occurrence, structure, regulation and eradication. Food Research International, v.45, ed.2, p.502-531, 2012. Available from: $<$ https://pubag.nal.usda.gov/catalog/414876>. Accessed: Oct. 25, 2018. doi: 10.1016/j.foodres.2011.01.038.

STEPANOVIC, S. et al. Biofilm formation by Salmonella spp. and Listeria monocytogenes on plastic surface. Letters in Applied Microbiology, v.38, p.428-432, 2004. Available from: <https:// www.ncbi.nlm.nih.gov/pubmed/15059216>. Accessed: Oct. 28, 2018. doi: 10.1111/j.1472-765x.2004.01513.x.

TORTORA, G.R. Microbiology. $10^{\mathrm{a}}$ Ed. Porto Alegre: Artmed. 2012.

EUROPEAN UNION, 2001a. Directive 2001/471 / EC of 21 June 2001. Rules for regular checks on the general hygiene of establishments. European Community Commission, Europe. Available from: <https://publications.europa.eu/en/ publication-detail/-/publication/99e23ed5-0cac-44f0-adc5a511f22c83f9/language-en>. Accessed: Nov. 12, 2018. doi: JOL.2001.165.R.0048.01. 
EUROPEAN UNION, 2001b. BS-EN 13697:2001: Quantitative Non-Porous Surface Test for the Evaluation of Bactericidal and / or Fungicidal Activity of Chemical Disinfectants used in Food, Industrial, Domestic and Institutional Areas. Test Method and requirements without Mechanical Action. Brussels, Belgium: European Committee for standardization. Available from: $<$ http:// www.disinfectant-info.co.uk/>. Accessed: Nov. 24, 2018.

USDA, United States Department of Agriculture. Pathogen Modeling Program - Models. Version 8.0. 2017. Available from: $<$ https://www.ars.usda.gov/northeast-area/wyndmoor-pa/easternregional-research-center/residue-chemistry-and-predictivemicrobiology-research/docs/pathogen-modeling-program/ pathogen-modeling-program-models/>, Accessed: Mar. 10, 2018.

VESTBY, L.K. et al. Biofilm forming abilities of Salmonella are correlated with persistence in fish meal- and feed factories. BMC Veterinary Research, v.5, p.20, 2009. Available from: <https:// www.ncbi.nlm.nih.gov/pubmed/19473515>. Accessed: Dec. 2, 2018. doi: 10.1186/1746-6148-5-20.

VIALTA, A.; et al. Good Manufacturing Practices, Hygiene and Hazard Analysis and Critical Control Points in the Dairy Industry. Dairy Industry, Porto Alegre: Artmed. v.37, 56p, 2002.
WANG, H.H. et al. Biofilm formation of meat-borne Salmonella enterica and inhibition by the cell-free supernatant from Pseudomonas aeruginosa. Food Control, v.32, p.650-658, 2013. Available from: <https://www.sciencedirect.com/science/article/ pii/S0956713513000704>. Accessed: Dec. 7, 2018. doi: 10.1016/j. foodcont.2013.01.047.

WHO, 2016. World Health Organization. Global Network Global Foodborne Infections Network. Global Salm Surv. 2016. Available from: <http://thor.dfvf.dk/pls/portal/GSS. COUNTRY_DATA_SET_REP.show_parms $>$. Accessed: May, 5, $201 \overline{7}$.

WHO, World Health Organization. Health Topics: Salmonella. 2017a. Available from: <http://www.who.int/foodsafety/ areas_work/foodborne-diseases/salmonella/en/>. Accessed: Nov. $\overline{8}, 2017$.

YANG, Y. et al. Biofilm formation of Salmonella Enteritidis under food-related environmental stress conditions and its subsequent resistance to chlorine treatment. Food Microbiology, v.54, p.98105, 2016. Available from: <https://www.sciencedirect.com/ science/article/pii/S0740002015001951>. Accessed: Dec. 9, 2018. doi: 10.1016/j.fm.2015.10.010. 